\title{
O PEWNYM ,KAZACHSKIM” PETROGLIFIE I JEGO „PODRÓŻY” W CZASIE I PRZESTRZENI. REFLEKSJA O SPOŁECZNEJ ADAPTACJI PRZESZŁOŚCI
}

\author{
ABOUT A "KAZAKH" PETROGLYPH AND ITS "JOURNEY" \\ IN TIME AND SPACE. REFLECTION ON SOCIAL ADAPTATION \\ OF THE PAST
}

\author{
Andrzej Rozwadowski
}

Instytut Wschodni, Uniwersytet im. Adama Mickiewicza, ul. 28 Czerwca 1956 r., 198, 61-486, Poznań, Poland

\begin{abstract}
Author of the paper discusses social implications of the choice of a prehistoric rock art image as a graphic symbol of the Institute of Ethnology and Cultural Anthropology of the Adam Mickiewicz University. The essay is divided into two parts. The first one deals with implications which result from using a petroglyph as a rock art image. In this matter the paper stresses interpretative context of reading this petroglyph in terms of otherness, both on formal and epistemological levels. In the second part the author considers implications which result from choosing this particular petroglyph, which comes from Kazakhstan. Author demonstrates different social involvements of such a choice, which however well define a nature of cultural anthropology as an academic discipline, which, by definition, faces numerous epistemological and ethical dilemmas in its practice.
\end{abstract}

Sztuka naskalna, a ściślej: motywy sztuki naskalnej, wykorzystywane są w różnorodnych sferach współczesnej przestrzeni publicznej. Wielorakie są też motywacje ich wyborów oraz cele, jakim mają służyć. Mogą stanowić inspirację dla współczesnych artystów, którzy przez adaptację pradziejowych motywów dążą do rewitalizacji zapomnianej tradycji ${ }^{1}$; mogą też stanowić ważny element kreowania tożsamości narodowej na poziomie symboliki państwowej, jak to ma miejsce w przypadku godła Republiki Południowej Afryki ${ }^{2}$. Często są też wykorzystywane

\footnotetext{
* Artykuł został napisany w ramach realizacji projektu NCN „Prahistoria szamanizmu syberyjskiego w świetle analizy sztuki naskalnej: symbolika i dynamika tradycji” DEC-2011/01/B/HS3/02140.

${ }^{1}$ Vervoort 2001.

${ }^{2}$ Smith et al. 2000.
} 
bardziej przygodnie, stając się na przykład motywami okładek książek (niekoniecznie archeologicznych lub antropologicznych), by nie wspomnieć o T-shirtach. W tym ostatnim przypadku o ich wyborze decyduje, jak można przypuszczać, ich niejednoznaczność, mogąca wywoływać u odbiorcy skojarzenia z tajemniczością, niejednoznacznością czy odwieczną kreatywnością człowieka. Abstrakcyjność formalna licznych motywów sztuki naskalnej, skutkująca ich nieoczywistością semantyczną, może jawić się szczególnie atrakcyjnie w tym kontekście. Adaptacje motywów sztuki naskalnej mogą być zatem konkretne i w pełni uświadomione, jak również bardziej przygodne. Zdarza się też, że motywy pradziejowej sztuki naskalnej są wybierane na graficzne symbole określonych instytucji lub organizacji.

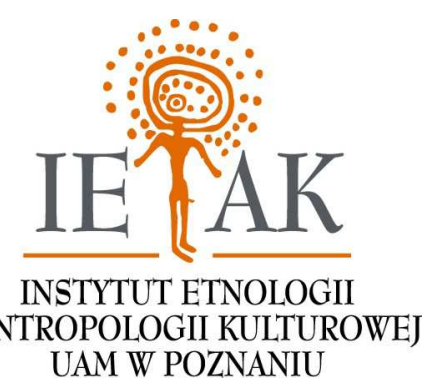

Ryc. 1. Logo Instytutu Etnologii i Antropologii Kulturowej UAM w Poznaniu

Fig. 1. The logo of the Institute of Ethnology and Cultural Anthropology of Adam Mickiewicz University in Poznań W tym przypadku również motywacją wyboru może być sama atrakcyjność formalna. Jeśli jednak motyw taki adaptowany jest przez organizację naukowo-badawczą, zakładać można, że oprócz walorów formalnych istotne winny być też inne kwestie, które były uświadomione i celowe. Jednym z takich przypadków instytucjonalno-naukowego użycia sztuki naskalnej, który stał się bezpośrednią inspiracją do napisania tego artykułu, jest nowe logo Instytutu Etnologii i Antropologii Kulturowej (IEiAK) Uniwersytetu im. Adama Mickiewicza w Poznaniu. Jego środkowym elementem jest właśnie pojedynczy motyw środkowoazjatyckiej sztuki naskalnej, który w tymże projekcie graficznym zastępuje spójnik ,i”, po obu stronach otoczony inicjałami poszczególnych słów nazwy instytutu „IE i AK” (ryc. 1). Biorąc pod uwagę, że jest to instytut naukowy, można przyjąć, że wybór motywu sztuki naskalnej w tym przypadku nie był uwarunkowany wyłącznie względem estetycznym, ale był celowy także aspekt semantyczny, z założeniem konotowania treści ważnych dla postrzegania Instytutu. W tym krótkim eseju chcę zastanowić się nad społecznym wydźwiękiem tego logo - nad tym, w jakim stopniu motyw sztuki naskalnej odzwierciedla idee badań antropologicznych. W jakiej mierze w końcu wpisuje się on w szerszy dyskurs społeczny przez sięgnięcie po „kazachski" motyw sztuki naskalnej. Poszukując odpowiedzi na te pytania, artykuł podzieliłem na dwie części. W pierwszej koncentruję się na kwestii wykorzystania po prostu motywu sztuki naskalnej jako takiego, w drugiej uwagę skupiam na implikacjach wynikających z użycia motywu „kazachskiego”. W tym miejscu pragnę zaznaczyć, iż odpowiedzi na te pytania poszukuję we własnej refleksji, jako osoba „,z zewnątrz”. Brakuje bowiem na stronie internetowej IEiAK wskazówek, jak należałoby odczytywać ten znak graficzny oraz jaka była historia jego powstania. 


\section{WIZERUNEK JAKO PETROGLIF}

Konieczność własnej interpretacji jest w moim odbiorze pierwszą zasadniczą wskazówką do tego, jakiego rodzaju tożsamość ma wyrażać to logo, samo zaś słowo „interpretacja” uznać można za klucz do jego dekonstrukcji. Myślę, że nie będzie nadużyciem twierdzenie, że dzisiejsza humanistyka, a w tym i antropologia, jest obecnie w istotnej mierze kształtowana paradygmatem interpretacyjności. Szczególnie ważną pozycję z pewnością należy przypisać w tej kwestii antropologii, jako nauce, która dużą wagę przywiązuje do zrozumienia tych uwarunkowań kultury. W opinii samych przedstawicieli dyscypliny antropologia może być uznana za wręcz „wzorcową" dyscyplinę w kręgu nauk humanistycznych, w tym sensie, iż „poprzez ekstremalne spiętrzenie trudności poznawczych, poczynając od kwestii rozstrzygnięć filozoficznych i epistemologicznych, a kończąc na problemach etycznych, na jej przykładzie najlepiej unaoczniają się pułapki stojące przed wszystkimi badaczami zjawisk intencjonalnych"3. Dlaczego zatem motyw sztuki naskalnej? W moim odczuciu w pierwszej kolejności wynika to ze znacznej, by nie powiedzieć ogromnej, enigmatyczności sztuki naskalnej, przynajmniej w ogólnym odbiorze społecznym. Przeświadczenie o tajemniczości sztuki naskalnej nie jest jednak tylko cechą popularnych opinii, ale długo cechowało także dyskurs naukowy. Jeszcze stosunkowo niedawno dosyć powszechna była opinia, iż sztuka naskalna to pole do nieograniczonych spekulacji interpretacyjnych. I choć nadal można spotkać się z tą opinią, to warto zwrócić uwagę na istotny przełom, jaki dokonał się, lub przynajmniej zaczął dokonywać, w ostatnich trzech dekadach. Najważniejszym znakiem tego intelektualnego ,poruszenia” stała się pogłębiona refleksja metodologiczna dotycząca rozumienia sztuki naskalnej i jej miejsca w kulturze, czego świadectwem są nowatorskie monografie czy wręcz kompendia badań sztuki naskalnej ${ }^{4}$. Światło dzienne ujrzały liczne opracowania regionalne oraz specjalistyczne periodyki lokalne i te o zasięgu międzynarodowym (jak np. Rock Art Research). Jeżeli dodamy do tego specjalistyczne instytuty czy centra uniwersyteckie powołane wyłącznie do badania sztuki naskalnej ${ }^{5}$, to wszystko to decyduje o tym, że studia nad sztuką naskalną coraz wyraźniej zyskują podmiotowość, choćby na polu ogólnie rozumianej archeologii, z którą najczęściej są kojarzone.

Wykorzystanie motywu sztuki naskalnej niewątpliwie można uznać za naturalną reakcję na powszechną dziś wizualność kultury. Ten zwrot w wyrażaniu się kultur -

\footnotetext{
${ }^{3}$ Burszta 1992, 118.

${ }^{4}$ McDonald, Veth 2012; Whitley 2001, 2005; Chippindale, Taçon 1998.

${ }^{5}$ Wymienię tylko niektóre: Rock Art Research Institute (Witwatersrand University, Johannesburg), Rock Art Research Centre (Australian National University, Canberry), Center for Rock Art Research (University of Western Australia, Perth), Deer Valley Rock Art Center (Arizona State University, Phoenix); czy też niezależne organizacje, takie jak Centro Camuno di Studi Preistorici (Capo di Ponte, Włochy) lub Trust for African Rock Art.
} 
coraz bardziej obrazowym aniżeli tylko słownym - implikuje refleksję dotyczącą zrozumienia ,inności” drugiej kultury, a więc pierwotnego celu badań antropologicznych, który w tym wymiarze nierozerwalnie łączy się z problemem przekładu: ,jak wyrazić znaczenia zawarte w jednym systemie wyrażania za pomocą wyrażania się przynależącego do systemu drugiego"6. Trudność tego zabiegu może zatem dobrze symbolizować, na co inicjalnie już wskazałem, sztuka naskalna. Jeśli zatem zinterpretować logo IAiEK jako graficzną refleksję nad współczesnymi dylematami poznania „inności”, to nie tylko sam wybór sztuki naskalnej mógłby być odebrany jako trafne posunięcie, lecz także szczególną wartość można dostrzec w tym konkretnym petroglifie. Jakie cechy wybranego motywu mogą przemawiać na korzyść tej tezy?

Po pierwsze, wybrany motyw jest niejednoznaczny. Nieoczywistość to poniekąd immamentna cecha jakiejkolwiek sztuki czy wręcz jakiegokolwiek wizerunku. W sztuce naskalnej ten walor jeszcze bardziej się potęguje, jej niejednoznaczność dotyczyć może bowiem kilku poziomów. Z perspektywy studiów nad sztuką naskalną można wskazać trzy: formalny, dokumentacyjny i znaczeniowy.

Jeżeli spojrzeć na wizerunek z perspektywy formalnej, to na podstawie jego oglądu trudno udzielić odpowiedzi na pytanie, co ten motyw przedstawia (w sensie deskryptywnym). Niewątpliwie jest to postać antropomorficzna, ale jej głowa lub to, co zastępuje jej głowę, wywołuje dylemat. Wybór zatem tego motywu z jednej strony jeszcze raz podkreśla interpretacyjność poznania, z drugiej zaś wskazuje na człowieka będącego „przedmiotem” tego poznania. Fakt, że motyw pochodzi z innego kontekstu kulturowego (czego postronny odbiorca nie musi wiedzieć), może dodatkowo podkreślać, że tym człowiekiem jest „Inny”.

Drugi poziom nieoczywistości dotyczy dokumentacji, co ma wymiar ,praktyczno-teoretyczny”. Na logo wybrano kopię petroglifu autorstwa kazachstańskiego archeologa - Ałana Gieorgijewicza Miedojewa ${ }^{7}$. Należy jednak zauważyć, iż kopia ta jest raczej niedoskonała; dokumentacja sztuki naskalnej autorstwa Miedojewa dziś już nie jest akceptowana na gruncie naukowym. W ostatnich latach, jeszcze przed wyborem tego motywu do poznańskiego logo, petroglif ten dokumentowano przynajmniej kilka razy ${ }^{8}$. Choć wypowiedź autora na temat własnej dokumentacji może być odebrana jako mało przekonująca, to jednak pozostanę na stanowisku, iż porównując kopię Miedojewa z rzeczywistem rytem in situ (ryc. 2), nie miałem wątpliwości, iż kopia ta nie jest dokładna. Wprawdzie można powiedzieć, że nie musi chodzić o wierność, a bardziej o sam fakt „,iekawego”, niejednoznacznego petroglifu postaci antropomorficznej. Przyjęcie tej interpretacji wydaje się zresztą zasadne

\footnotetext{
${ }^{6}$ Burszta 1992, 156.

${ }^{7}$ Miedojew 1979.

${ }^{8}$ Maksimowa et al. 1985, 31; Anati 1994, 122; Rogożinskij 2001, 12; Rozwadowski 2001, 68;
} 2003, 201. 
w kontekście uwag wyżej zgłoszonych. W dobie dzisiejszej antropologicznej refleksji nad poznaniem można by nawet powiedzieć, że poszukiwanie najwierniejszej kopii mija się z celem. Kopia zawsze jest kopią, każda dokumentacja jest redukcją informacji. Tak jak w pewnym momencie zakwestionowano obiektywność obserwacji uczestniczącej, aspirującej w swoim czasie do metody mającej zapewnić bezpośredni dostęp do badanej kultury, tak dokumentacja sztuki naskalnej z pewnością nigdy nie jest w pełni kompletna. Zawsze coś pomijamy, nie w wyniku naszej niestaranności, ale głównie naszej niewiedzy na temat tego, co winniśmy udokumentować i jak to zrobić. Uwagi te można by jeszcze mnożyć. Wniosek, jaki z nich wynika, jest taki, że dokumentacja nie jest procesem obiektywnym, jest warunkowana teoretycznie. Udokumentowanie „czegoś” zależy od wiedzy, jaką w danym momencie posiadamy, bo ta wiedza zadecyduje o naszym widzeniu danego obiektu czy zjawiska. To jedna $\mathrm{z}$ rozsądnych interpretacji. Nie można jednak wykluczyć i takiej, iż nie wiedziano o nowszych dokumentacjach. Wyłania się stąd pytanie, czy dokładność nie powinna jednak być cechą jakiejkolwiek nauki. Czy zatem dyskutowany fakt nieuwzględnienia aktualnej kopii rytu jest świadomym zabiegiem antropologicznym (co miałoby określoną wartość, jak starałem się pokazać), czy też może wynikać z innych przyczyn, jak chociażby nieznajomości stanu badań? Jako osoba z zewnątrz każdą z interpretacji mogę przyjąć za możliwą, gdyż mam przesłanki

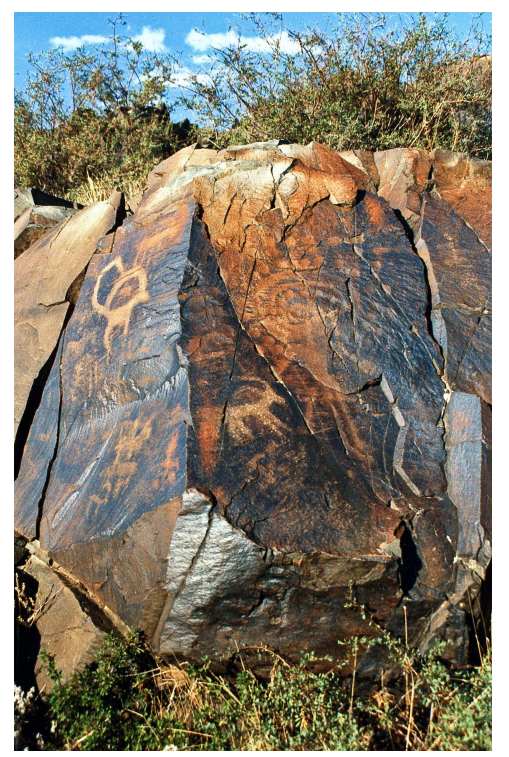

Ryc. 2. Blok skalny z petroglifem, który jest motywem logo IEiAK (fot. Andrzej Rozwadowski)

Fig. 2. The rock with the petroglyph used in the logo of the Institute of Ethnology and Cultural Anthropology (photo by Andrzej Rozwadowski) dla wiarygodności każdej z nich.

I wreszcie trzeci aspekt nieoczywistości - interpretacja znaczeniowa tego rodzaju motywów oscyluje zasadniczo wokół dwóch propozycji. W starszych studiach częściej spotyka się przeświadczenie, iż owe motywy są przedstawieniami bogów solarnych, nowsze analizy sugerują zaś, że może chodzić o graficzne ekspresje doznań wizyjnych, które mogły być udziałem szamanów ${ }^{10}$. Ponownie zatem ujawnia się aspekt niejednoznaczności.

\footnotetext{
${ }^{9}$ Zob. Lewis-Williams 1990.

${ }^{10}$ Rozwadowski 2001; 2003.
} 
Ważną motywacją wyboru tego motywu, jak można zakładać, powinna być jego semantyka. Ale logo nie byłoby skuteczne, gdyby przy wyborze nie uwzględniono również waloru estetycznego. Atrakcyjność formalna to coś jak najbardziej zrozumiałego w kreowaniu logo - winno ono zwracać na siebie uwagę. Łączy się to jednak z zabiegiem redukcji - wyboru jakiegoś fragmentu z większej całości. Dotyczy to też komentowanego wizerunku, który w rzeczywistości (tj. in situ) znajduje się na kamieniu, na którym można odnaleźć jeszcze inne wizerunki (np. kozła w bezpośredniej bliskości - ryc. 2), choć z innego punktu widzenia nie można mieć pewności, czy wszystkie motywy były jednym planem myślowym pierwotnego ,artysty”. Zatem w grę wchodzi partykularność wyboru, kolejna znamienna cecha współczesnego poznania świata, którą ten motyw sztuki naskalnej mógłby symbolizować. Przedmiot/temat badawczy wybierany jest ze względu na coś, jest warunkowany personalnymi zainteresowaniami badacza lub tym, co badacz „usłyszy”. Ten hermeneutyczny odwrót od klasycznej relacji poznawania podmiot-przedmiot na rzecz przedmiot-podmiot detronizuje badacza z pozycji tego, który pyta, na rzecz tego, który pytanie musi usłyszeć ${ }^{11}$. A że nie wszystko da się usłyszeć, badania kreowane są nie przez ,zdroworozsądkowy” namysł nad daną sytuacją, ale to sytuacja, sam świat, kreuje pytania, które badacz zaczyna słyszeć. Przedmiot badań jest stąd partykularną decyzją badacza, jakby ,,podpowiedzianą” przez świat.

\section{WIZERUNEK JAKO PETROGLIF „KAZACHSKI”}

Trudno podejrzewać intencję wyrażenia związku z jakąś konkretną sytuacją, kulturą lub kontekstem dziejowym, do którego przynależy ryt z Kazachstanu. Wybór pradziejowego petroglifu potencjalnie mógłby być bezpiecznym wyborem, łączność rytów naskalnych w Kazachstanie z określoną tradycją kulturową nie jest bowiem w pełni zidentyfikowana. Przynależą do przeszłości, co do której w chwili obecnej żadna z nacji zamieszkujących Kazachstan nie formułuje roszczeń w sposób bezpośredni. Teoretycznie nie można jednak wykluczyć zmiany takiej sytuacji w niedalekiej przyszłości, o czym mogą świadczyć niedawne głosy w sprawie ważności „kazachskich” petroglifów dla tożsamości etniczno-kulturowej Kazachstanu ${ }^{12}$. Świadomość faktu, iż sztuka naskalna jest w licznych kulturach postrzegana właśnie jako kanał łączności danej kultury z jej lokalną tradycją, nakazuje zastanowić się, w jakim stopniu wybór tego petroglifu może wpisywać się w przywołaną wcześniej sieć problemów poznawczo-etycznych ogniskujących uwagę antropologii. Włączenie symboli z przeszłości w teraźniejszość nie jest pozbawione oceny kulturowej i może zostać odebrane jako ingerencja w tożsamość danej kultury. Wydaje się, że

\footnotetext{
${ }^{11}$ Szulakiewicz 2004, 58.

${ }^{12}$ Yespembetova et al. 2008.
} 
łatwiej było podjąć decyzję o adaptacji petroglifu z Kazachstanu aniżeli na przykład motywu sztuki naskalnej rdzennych mieszkańców Australii, dla których malowidła naskalne są żywym wymiarem pamięci kulturowej i jako takie są prawnie chronione - ich publiczne użycie może być obwarowane zgodą starszyzny plemiennej. Ale Australia jest oczywiście najbardziej ,,czułym” przykładem. Odwołam się zatem do przykładu z kontynentu amerykańskiego, do rytów w Peterborough w Kanadzie, również pochodzących z czasów prahistorycznych, ale traktowanych przez Odżibwejów jako świadectwo ich tradycji (trudnej jednak do jednoznacznego wykazania na gruncie naukowym) ${ }^{13}$. Sztuka ta zaczyna przynależeć do danej kultury poniekąd przez zasiedlenie. To jakby powiedzieć: ,jest ona nasza, gdyż powstała na naszej ziemi”. Uwaga ta ma pewne konsekwencje również w odniesieniu do logo IAiEK. Kazachstan, jak i inne kraje rejonu Azji Środkowej, zyskał status niepodległego państwa stosunkowo niedawno, bo w 1991 r. Stanął zatem wobec nowych wyzwań, wśród których kwestie tożsamości kulturowej i archaiczności lokalnej kultury zaczęły odgrywać coraz ważniejszą rolę właśnie po 1991 r. $^{14}$. Przeszłość w Azji Środkowej dosyć szybko stała się zakładnikiem dyskursu politycznego ${ }^{15}$. Nie tylko ta relatywnie niedawna (np. gloryfikacja Timura w Uzbekistanie czy tzw. renesansu perskiego w Tadżykistanie), lecz także ta o znacznie dłuższej metryce. Jeden z najbardziej gorących sporów ostatnich lat w tym rejonie został wywołany przez odkrycie mumii młodej kobiety w kurhanie z epoki żelaza na płaskowyżu Ukok w górach Ałtaju (w rosyjskiej części Ałtaju), przynależącej do kultury wczesnych koczowników, tzw. Saków syberyjskich ${ }^{16}$. Podobnie jak w przypadku „odżibwejskich” petroglifów w Peterborough, również tutaj trudno stwierdzić ałtajskość tej mumii, jeśli ałtajskość ma być rozumiana z perspektywy języka. Jeśli przyjmie się za słuszną powszechną identyfikację Saków z etnosem irańskim, to jej ałtajskość (języki ałtajskie przynależą do tureckiej/turkijskiej grupy językowej w tej części Syberii) może być kwestionowana. Ale poza językiem, czy nawet typem antropologicznym (istnieje także spór o mongolskość lub europoidalność tej kobiety), lokalność można mierzyć także charakterem kultury - w tym wypadku nomadyczno-stepowej z licznymi konsekwencjami za tym idącymi, jak na przykład możliwym systemem wyobrażeń o świecie. Z tej perspektywy „księżniczka” z Ałtaju jest w oczach Ałtajczyków w pełni reprezentantką ich kultury, która po dziewiętnastu latach od jej odkrycia i eksponowania w uniwersyteckim Muzeum Archeologii i Etnografii w Nowosybirsku ostatecznie we wrześniu 2012 r. powróciła do Gorno-Ałtajska, gdzie wybudowano dla niej osobną, nową cześć muzeum. Ten przypadek istotne łączy się z symboliką współczesnego Kazachstanu i wykorzystaniem sztuki pradziejowej. W godle

\footnotetext{
${ }^{13}$ Vastokas, Vastokas 1973.

${ }^{14}$ Shukuralieva 2011.

${ }^{15}$ Marat 2008; Shnirelman 2010.

${ }^{16}$ Polosmak 2001.
} 
państwowym Kazachstanu obecne są bowiem motywy uskrzydlonego konia, zdobiące nakrycie głowy tzw. Złotego Człowieka, tj. osoby odkrytej w kurhanie sakijskim w rejonie Siedmiorzecza (Żetysu), niedaleko Ałmaty. Analogicznie, jak w przypadku mumii ałtajskiej, symbole Saków z terenu współczesnego Kazachstanu zostały symbolami tożsamości kulturowej Kazachów. Z tej perspektywy wydaje się, że sięgniecie po jeszcze starsze przykłady sztuki pradziejowej (a więc petroglify), jako symbole nowego państwa, uznać można za pewną konsekwencję.

Jeśli zaufać aktualnym ustaleniom archeologicznym, to dyskutowany petroglif pochodzi z czasów epoki brązu, tj. z drugiego tysiąclecia p.n.e. Mówienie o kazachskości w odniesieniu do tak odległych czasów oczywiście byłoby nadużyciem. Ale podobnie jak na Ałtaju, tak i w kazachstańskim przypadku zaczyna bardziej chodzić o znalezienie pewnych cech wspólnych z lokalną kulturą (jak np. nomadyzm). Okazuje się, że w ostatnich latach petroglify z Tamgały zaczynają właśnie pełnić funkcję wyznacznika tożsamości kulturowej Kazachstanu. Nie tylko na gruncie dociekań naukowych ${ }^{17}$, lecz także (i poprzez te dociekania) w szerszej przestrzeni publicznej. Trzeba tutaj dodać, że petroglify doliny Tamgały zostały w $2004 \mathrm{r}$. wpisane na listę światowego dziedzictwa UNESCO, stając się pierwszym zespołem sztuki naskalnej w Azji Środkowej, który został tak wyróżniony w skali globalnej. Stąd zrozumiała coraz częstsza koncentracja uwagi społecznej na tychże petroglifach. Być może zatem nie jest aż takim zbiegiem okoliczności fakt, iż ten sam motyw, który jest w logo IEiAK, zaczęto wykorzystywać do promowania Kazachstanu na poziomie międzynarodowym. Jest on emblematem okolicznościowej złotej monety o nominale 50000 tenge (ok. 1000 PLN), wydanej przez Kazachstański Bank Narodowy (KBN) z okazji Siódmych Azjatyckich Igrzysk Zimowych, które odbyły się w Ałmaty w 2011 r. (powtórzonej także w srebrze o nominale 500 tenge). Ten sam motyw znajduje się na podobnej okolicznościowej monecie należącej do serii „Petroglify Kazachstanu”18. Na początku 2013 r. KBN wydał kolejne dwie okolicznościowe srebrne monety o nominale 500 tenge o nazwie „Petroglify Tamgały” z tymże samym wizerunkiem „Bóstwa Solarnego”, które wchodzą w skład serii monet nazwanych „Narodowe Dziedzictwo"19 (warto odnotować, że motywy sztuki naskalnej obecne są również na innych kazachstańskich banknotach, a oprócz nich także inne motywy pradziejowej sztuki sakijskiej - tradycja nomadów epoki żelaza zostaje zatem zaadaptowana państwowo). Inny motyw z Tamgały, także z grupy solarnych antropomorficznych petroglifów, w nowej stylizacji funkcjonuje jako logo festiwalu muzycznego „Głos Azji”, odbywającego się corocznie w Ałmaty. Motyw $\mathrm{z}$ logo IEiAK pojawia się także na tle strony internetowej Biblioteki Narodowej

\footnotetext{
${ }^{17}$ Yespembetova et al. 2008.

${ }^{18}$ Zob. http://www.nationalbank.kz/index.cfm?docid=29

${ }^{19}$ National Bank released Petroglyphs of Tamgaly commemorative coins http://en.tengrinews.kz/ finance/National-Bank-released-Petroglyphs-of-Tamgaly-commemorative-coins-15439 (dostęp: 2.02.2013).
} 
Republiki Kazachstanu (http://www.nlrk.kz). Sztuka naskalna doliny Tamgały jest też inspiracją dla niektórych współczesnych artystów kazachstańskich, którzy w poszukiwaniu nowej tożsamości artystycznej sięgają do dawnej i tradycyjnej sztuki „kazachskiej”"20. Obraz Kadyrżana Chajrulina, Rok aktywnego stońca (z 1989 r.), koncentruje się na solarnych petroglifach, wśród których jest też motyw z logo IEiAK. Tymi samymi motywami inspirowany jest obraz innego kazachstańskiego artysty, Jewgenija Dorochowa, Sakrament milczenia, namalowany w 1992 r. $^{21}$ Można by wskazać i na inne uwikłania tego petroglifu we współczesnym dyskursie społeczno-politycznym Kazachstanu, jak i szerzej - Azji Środkowej. Odwołanie się do nomadycznej przeszłości, do symboli solarnych (a więc związanych z Niebem), to kluczowe wątki silnie manifestowanej po $1991 \mathrm{r}$. nowej ideologii tengryzmu/tengrianstwa, wokół której niektórzy intelektualiści regionu widzą nową przestrzeń kreowania pantureckiej/panturkijskiej tożsamości nomadów Azji Środkowej $^{22}$.

Sztuka naskalna w Kazachstanie zatem nie jest już dziś źródłem „neutralnym”, ale staje się elementem szerszego dyskursu społecznego, koncentrującego się wokół tożsamości Kazachów i kształtującego się państwa Kazachstan. Przytoczone wcześniej słowa o antropologii jako dyscyplinie, w której „wzorcowo” objawiają się wszelkie problemy przenikające współczesny świat humanistyki (takie jak trudności poznawcze i problemy etyczne), okazują się tu dobrze sprawdzać. Można więc powiedzieć, że ,na tle” całej złożoności współczesnego poszukiwania nowej tożsamości Kazachstanu petroglif ten w wyrazisty sposób obrazuje te problemy, które z definicji winny koncentrować uwagę antropologa kultury.

Nurtujący pozostaje fakt, iż logo zazwyczaj odnosi do pewnej specjalizacji badawczej danej organizacji. Nie dziwią zatem motywy sztuki naskalnej jako symbole organizacji i instytucji badających lub promujących sztukę naskalną. To, że sztuka naskalna nie stanowi osobnego programu badawczego IEiAK, może pozostawiać w związku z tym pewien niedosyt (choć należy odnotować zasłużoną i rozpoznawalną poznańską szkołę etnologii Azji Środkowej). Ale chociaż sztuka naskalna tradycyjnie kojarzona jest $\mathrm{z}$ archeologią, to trzeba podkreślić, że stanowi ona także przedmiot dociekań etnologicznych, a w ostatnich latach uwzględnianie kontekstu etnologicznego w studiach nad sztuką naskalną stało się niejednokrotnie wręcz priorytetem badawczym ${ }^{23}$. Patrząc zaś na historię badań nad sztuką naskalną, można nawet powiedzieć, że perspektywa antropologiczna była często wręcz głównym

\footnotetext{
${ }^{20}$ Puzanowa 2008.

${ }^{21}$ Zob. http://www.admomsk.ru/web/guest/news/gallery/-/asset_publisher/rZ0y/content/297239 (dostęp: 15.03 .2014$)$

${ }^{22}$ Laruelle 2007.

${ }^{23}$ Keyser et al. 2006; Blundell et al. 2010.
} 
stymulatorem licznych przewartościowań w sferze rozumienia tej kategorii źródeł ${ }^{24}$. Spoglądając z tej perspektywy na logo IEiAK (z odrobiną zazdrości, gdyż osobiście w zakresie badawczym bym się z nim identyfikował), zastanawiam się, czy nie można by go odczytać w kategoriach zaproszenia do interdyscyplinarnej współpracy. Myśl ta jest inspirowana odległym, acz w pewnym stopniu podobnym, przykładem użycia motywu sztuki naskalnej, który przywołano na samym początku niniejszego eseju. Chodzi o godło Republiki Południowej Afryki ${ }^{25}$. Motyw postaci ludzkiej, znajdujący się centrum godła RPA, zaczerpnięty z buszmeńskich malowideł naskalnych i opatrzony dodatkowo mottem wyrażonym w wymarłym buszmeńskim języku Xam: !Ke e: xarra //ke, co znaczy „Różni ludzie łączcie się”26, jest formą zaproszenia (,zmuszenia”) do wysiłku poznania swojej tradycji, swojej przeszłości, która winna jednoczyć, gdyż jest wspólna - afrykańska i rdzenna. Tak jak buszmeński motyw w godle RPA jest zaproszeniem do zniesienia różnic i wzajemnego współdziałania na rzecz przyszłości, być może moje odczytanie logo IEiAK mogłoby się stać czymś analogicznym w zakresie ściślejszej współpracy antropologii $\mathrm{z}$ archeologią, które przecież historycznie i tematycznie łączy wiele ${ }^{27}$. Sztuka naskalna akurat jest też jednym z tych aspektów kultury, w której badaniu obie dyscypliny mogą szczególnie twórczo współdziałać. Najnowszym tego sygnałem może być A companion to rock art, praca wydana w serii „Blackwell Companions to Anthropology"28.

\section{PODSUMOWANIE}

Moje poszukiwania wielorakich wydźwięków społecznych logo IEiAK może były nader indywidualne, ale, jak zaznaczyłem na wstępie, brak wyraźnych wskazówek co do intencji użycia (tego) petroglifu poniekąd zmusza do jego interpretacji. Nawet jeśli takowe by istniały, to prześledzenie nowych (tj. już po sformułowaniu tego logo) form adaptacji tego petroglifu ma w moim odczuciu określoną wartość poznawczą. Podkreślić jednak należy, że dynamika procesów społeczno-kulturowych, szczególnie w rejonie, który po rozpadzie ZSRR poszukuje nowych form identyfikacji, sprawia, że z pewnością nie sposób przewidzieć wszystkich możliwych implikacji określonych decyzji. Mimo zgłoszonych w tym eseju pewnych dylematów związanych z odbiorem tego logo, w większości podniesionych kwestii

\footnotetext{
${ }^{24}$ Rozwadowski 2009.

${ }^{25}$ Smithet al. 2000.

${ }^{26}$ Hromnik 2001; por. Bernard 2004.

${ }^{27}$ Buchowski et al. 2012.

${ }^{28}$ McDonald, Veth 2012.
} 
dopatruję się jednak adekwatności wyboru tego motywu jako graficznego symbolu antropologii i pytań, które nurtują badacza kultury. Już po napisaniu zasadniczego trzonu tego tekstu i kiedy tuż przed jego publikacją mogłem jeszcze zrobić drobne korekty, ujawnił się jeszcze nowszy szczebel kariery dyskutowanego tutaj petroglifu. Narodowa reprezentacja Kazachstanu na Zimowych Igrzyskach Olimpijskich w Soczi wystąpiła w strojach, których „ozdobą” był tenże właśnie petroglif (ryc. 3)

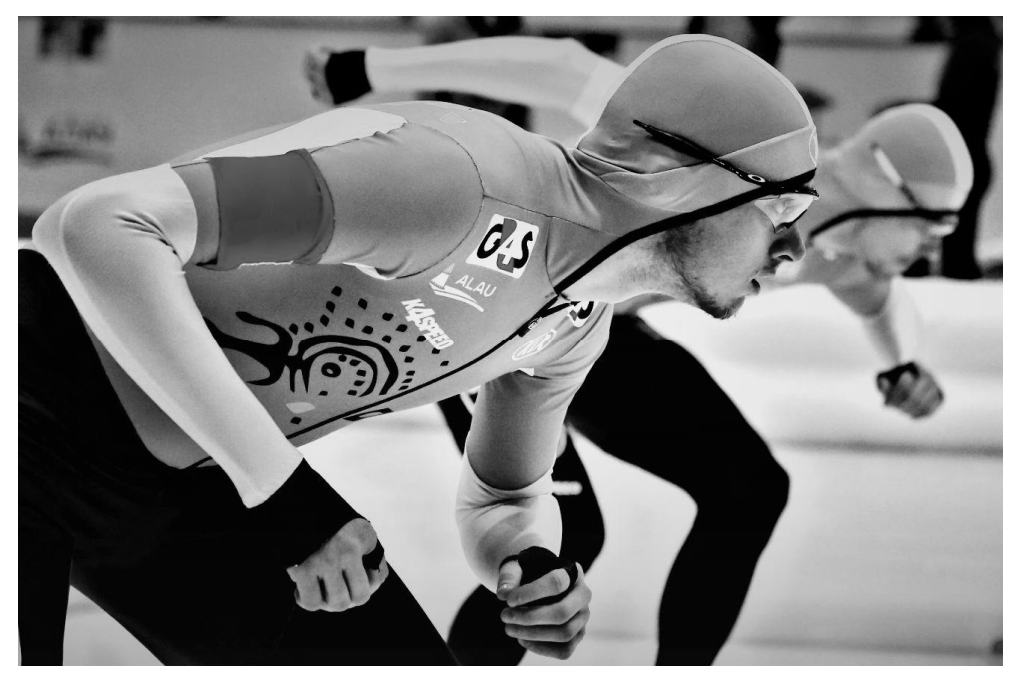

Ryc. 3. Denis Kuzin - reprezentant Kazachstanu w jeździe szybkiej na lodzie w kombinezonie z motywem petroglifu solarnego z Tamgały ( $w$ analogicznych strojach występowali inni reprezentanci), http://www. sports.ru/tribuna/blogs/skatingkz/527792.html?comments=1 (dostęp: 15.03.2014)

Fig. 3. Denis Kuzin - representative of Kazakhstan in speed skating in an outfit with a solar motif petroglyph from Tamgaly (analogus outfits were worn also by other Kazakh representatives), http://www. sports.ru/tribuna/blogs/skatingkz/527792.html?comments=1 (access 15.03.2014)

(a na innych strojach, np. prezentowanych podczas ceremonii otwarcia Igrzysk i powitań poszczególnych reprezentacji, także inne motywy sztuki naskalnej z terenu Kazachstanu). Sytuacja jest zatem ciekawa nie tylko z perspektywy ciągle trwającej „podróży” tego petroglifu, lecz także studiów nad sztuką naskalną. Trend wykorzystywania pradziejowej sztuki naskalnej we współczesnej przestrzeni publicznej Azji Środkowej, a także Syberii (patrząc tylko na obszar poradziecki), jest coraz żywszy i wpisuje się w szerszy proces etnizacji (lub ,archeologizacji”, jak niektórzy to określają) współczesności. Na koniec pragnąłbym zaznaczyć, że moja wypowiedź w żadnym stopniu nie miała zamiaru krytyki IEiAK lub jakiekolwiek osoby z nim związanej. 


\section{BIBLIOGRAFIA}

Anati E.

$1994 \quad$ World rock art: the primordial language, Capo di Ponte.

Bernard A.

2004 Coat of arms and the body politic: Khoisan imagery and South African national identity, Ethnos 69 (1), s. 5-22.

Blundell G., Chippindale C., Smith B. (red.)

$2010 \quad$ Seeing and knowing. Understanding rock art with and without ethnography, Walnut Creek.

Buchowski M., Mamzer H., Rozwadowski A., Posern-Zieliński A.

2012 Antropologia a archeologia [w:] Przeszłość społeczna. Próby konceptualizacji, red. S. Tabaczyński, A. Marciniak, D. Cyngot, A. Zalewska, Poznań, s. 686-712.

Burszta W.

1992 Wymiary antropologicznego poznania kultury, Poznań.

Chippindale C., Taçon P.S.C. (red.)

1998 The archaeology of rock-art, Cambridge.

Hromnik C.A.

2001 !Ke e: Ixarra ke - the Qena motto in the South African coat of arms, Quarterly Bulletin of the National Library of South Africa 56 (2), s. 65-72.

Keyser J.D., Poetschat G., Taylor M.W. (red.)

2006 Talking with the past. The ethnography of rock art, Portland.

Laruelle M.

2007 Religious revival, nationalism and the 'invention of tradition': political Tengrism in Central Asia and Tatarstan, Central Asian Survey 26 (2), s. 203-216.

Lewis-Williams J.D.

1990 Documentation, analysis and interpretation: dilemmas in rock art research, South African Archaeological Bulletin 45, s. 126-136.

Maksimowa A.G., Ermoljewa A.S., Marijaszew A.N.

1985 Naskalnyje izobrażenija urocziszcza Tamgały, Ałma-Ata.

Marat E.

2008 National ideology and state-building in Kyrgyzstan and Tajikistan (Seria "Silk Road Paper" January 2008), Washington D.C.

McDonald J.J., Veth P.M. (red.)

2012 A Companion to Rock Art, Oxford.

Miedojew A.

1979 Grawjury na skałach, Ałma-Ata.

Polosmak N.W.

2001 Wsadniki Ukoka, Nowosibirsk.

Puzanowa I.

2008 Współczesna sztuka Kazachstanu a świat nomadów 1991-2001 [w:] Sztuka Orientu, t. I: Studia nad sztuką Azji, red. J. Malinowski, J. Wasilewska, Toruń, s. 167-225.

Rogożinskij A.

2001 Izobrazitelnyj rjad petroglifow epochi bronzy swjatiliszcza Tamgały, [w:] Istoria $i$ archeologia Semireczja, red. A.N. Marjaszew, U.A. Motow, Ałmaty, s. 7-43.

Rozwadowski A.

2001 Sun gods or shamans? Interpreting the 'solar-headed' petroglyphs of Central Asia [w:]

The archaeology of shamanism, red. N. Price, London, s. 65-86. 


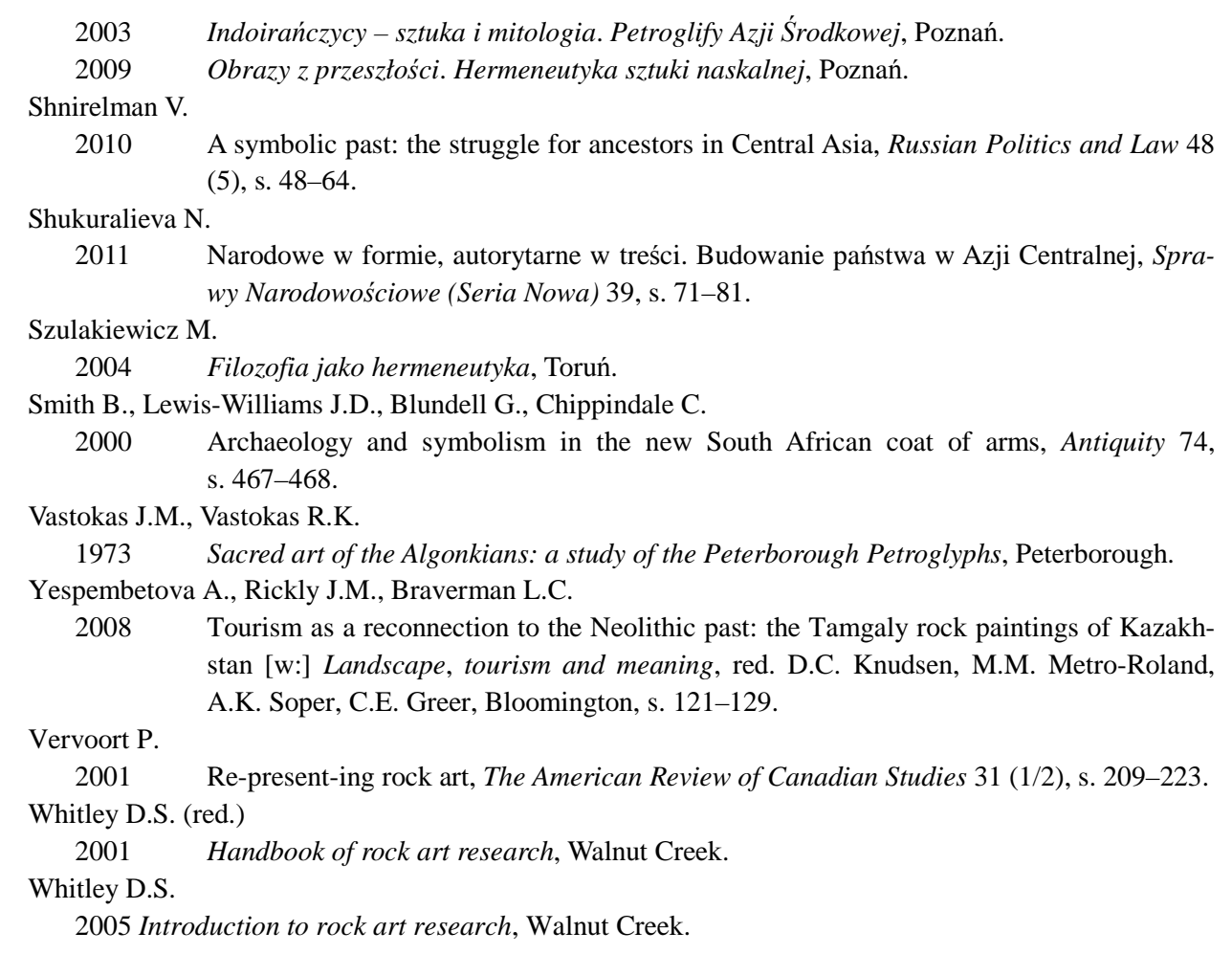

\section{ABOUT A “KAZAKH” PETROGLYPH AND ITS “JOURNEY” IN TIME AND SPACE. REFLECTION ON SOCIAL ADAPTATION OF THE PAST}

\section{S u m m a ry}

This paper is a polemic voice in discussion of contemporary social usage of rock art. Direct inspiration for writing this article was the new logo of the Institute of Ethnology and Cultural Anthropology of the Adam Mickiewicz University, which adapted a prehistoric petroglyph as a central symbol of its emblem. Taking into account that rock art images are often used as symbols of different organizations or just as decor of popular objects, the use of such a motif by scientific institution appears particularly interesting. Considering that any logo should express the "nature" of the symbolized institution, the paper wonders to what extent the petroglyph fulfills its function. Due to the lack of official explanation of how to understand this emblem, the author considers its possible readings and its social implications.

The paper is divided into two parts. The first one looks at usage of the petroglyph just as a rock art image. It is suggested that clue word for defying significance of the petroglyph for the anthropological emblem is "interpretation" - an action required for understanding of any other- 
ness. The ambiguity of chosen petroglyph directs to this idea differently. Unnatural head of the anthropomorphic figure causes the first interpretative dilemma (on formal level). The difference of this human figure refers further to space (image from Asia), time (prehistory), culture and language (contemporary Kazakhstan). Furthermore, ambiguity of the image deals also with semantics as different interpretations of this petroglyph has been proposed by researches. The last aspect of ambiguity concerns documentation - the petroglyph has been documented by different scholars and in consequence more than one drawing of this rock image is accessible. The one which has been chosen for the logo is an older and inaccurate copy. The choice of imprecise drawing then rises a question if such an adaptation of the image corresponds with "scientific" nature of the academic institution. On the other hand, however, theoretical reflection on relationship between documentation and interpretation makes this dilemma paradoxically be perceived as "mark" of anthropology.

In the second part of the paper the author discuses implications which result from using this particular petroglyph, which comes from Kazakhstan. Several implications have been pointed out. First, the petroglyph comes from ancient times of the Bronze Age and as such its ethnic identity is difficult to assign. Shortly, it comes from pre-Turkish times. As Kazakhs belong to Turkiclanguage-speaking peoples the petroglyph should not play a crucial role in a contemporary ethnic discourse. However, images from the Bronze Age rock art have recently started to be actively used politically to promote Kazakhstan officially (e.g. as images on coins) or more commonly (e.g. as symbols of festivals). Importance of these petroglyphs for Kazakh identity has recently been argued also by some Kazakh scientists. Even though their ethnic belonging can be debated, they are claimed to be signs of ancient nomadism, which constitutes a distinct feature of Kazakh traditional way of life. Furthermore, what is intriguing is the fact that exactly the same image has become one of most frequently copied image to promote Kazakhstan internationally. The image chosen by the anthropological institute is then an image which often appears in wider ethno-historical-political discourse in Kazakhstan. The archaeological past is currently actively explored by politicians and any past, though particularly the Bronze and Iron Ages, is politically sensitive. This particular petroglyph has also got further implications. It has been labeled a Solar God and, although one could argue if it is an appropriate naming, today it starts to be commonly accepted as dogma. As such, the image is believed to be a symbol of Sky, in Turkic languages defined as Tengri. And Tengri is a symbol of pan-Turkic ideological movement tengrism.

All these involvements of the Kazakh petroglyph make its position in the logo of the academic institute be interpreted differently. On the one hand, adopting the image so engaged in different contemporary dialogs makes risk for the institution to be unwillingly involved in sensitive discourses. On the other hand, however, it may be argued that the choice of this petroglyph perfectly expresses ethical and epistemological problems which by definition focus attention of cultural anthropology. 